\title{
Distributional patterns of shallow-water polychaetes in the Magellan region: a zoogeographical and ecological synopsis*
}

\author{
AMÉRICO MONTIEL SAN MARTÍN ${ }^{1,2}$, DIETER GERDES ${ }^{1}$ and WOLF E. ARNTZ ${ }^{1}$ \\ ${ }^{1}$ Alfred-Wegener-Institut für Polar- and Meeresforschung, Columbusstraße, 27568 Bremerhaven, Germany. \\ E-mail: amontiel@awi-bremerhaven.de \\ ${ }^{2}$ Centro de Estudio del Cuaternario de Fuego - Patagonia y Antártica Chilena (CEQUA), Punta Arenas, Chile.
}

\begin{abstract}
SUMMARY: The zoogeography of polychaete annelids was described for the Magellan region. This work considered information available from 19 expeditions carried out in the last 124 years of polychaete taxonomic research around the southernmost tip of the South American continental shelf. The polychaete fauna of the Magellan region comprised a total of 431 species belonging to 108 genera and 41 families. MDS and ANOSIM analyses showed the Magellan region to be divided into two subregions, one on the Pacific side of the tip of South America and one on the Atlantic side. These subregions showed a low percentage of "endemic species" $(<10 \%)$ whereas $>70 \%$ of the species recorded for the whole Magellan region showed a wide distribution range, and there were especially high affinities with Antarctic and Subantarctic areas. We suggest that the opening of the Straits of Magellan created a new pathway for enhanced exchange of faunal elements between the Pacific and the Atlantic. Transport of larvae via easterly directed currents of the West Wind Drift plays an important role in current distribution patterns of polychaete fauna around the tip of South America.
\end{abstract}

Keywords: polychaete zoogeography, Antarctic affinities, species composition, Magellan region.

RESUMEN: PATRONES DE DISTRIBUCIÓN DE LOS POLIQUETOS DE AGUAS SOMERAS EN LA REGIÓN MAGALLÁNICA: UNA SINOPSIS ZOOGEOGRÁFICA Y ECOLÓGICA. - Se describe la biogeografía de los poliquetos anélidos para la región de Magallanes, haciéndose referencia a la información disponible de 19 expediciones realizadas durante los últimos 124 años de investigación taxonómica en la plataforma del cono sur de Sudamerica. La fauna de poliquetos de la región de Magallanes esta constituida por un total de 431 especies pertenecientes a 108 géneros y 41 familias. El análisis de MDS y ANOSIM mostró que la región de Magallanes se puede dividir en dos subregiones biogeográficas, una del lado pacífico y otra del lado atlántico del cono sur de Sudamérica. Estas entidades biogeográficas se caracterizaron por un bajo porcentaje de especies endémicas $(<$ $10 \%$ ). Aproximadamente el $70 \%$ de las especies registradas en ambas subregiones mostró un amplio rango de distribución, especialmente se encontró una alta afinidad con áreas antárticas y subantárticas. Esto sugiere que la apertura del Estrecho de Magallanes creó un nuevo pasaje de intercambio de especies entre el Pacífico y el Atlántico. Además se sugiere que la dispersión vía transporte larvario a través de la Corriente de Deriva del Oeste estaría jugando un rol preponderante en el actual patrón de distribución de la fauna de poliquetos en la región de Magallanes.

Palabras clave: zoogeografía de poliquetos, afinidades antárticas, composición de especies, región de Magallanes.

\section{INTRODUCTION}

Polychaetes have been considered for zoogeographical analysis in South America only in the last

*Received June 3, 2004. Accepted June 28, 2005. decade (Lancellotti and Vásquez, 1999; Fernández et al., 2000; Camus, 2001; Glasby and Alvarez, 1999). They are thought to be inadequate indicators for zoogeographical purposes because of their wide geographical range at all taxonomic levels, and especially because of their long-distance dispersal 
capabilities. Paradoxically, polychaetes constitute worldwide a large portion of the total macrofauna of soft bottoms (Hutchison, 1998), and with more than 16,000 species known so far, they are the fourth major group of marine invertebrates (Blake, 1995; Bouchet, 2000). Although, with the exception of a few poorly-known ones, polychaete families occur in all oceans and at all depths, overview studies on species level, which would be required for zoogeographic analysis, are scarce in the polychaete literature, and the Magellan region is by no means an exception (e.g. Hartmann-Schröder and Hartmann, 1974; Knox and Lowry, 1977). According to Knox (1957) more than $40 \%$ of the southern hemisphere polychaete species are thought to be cosmopolitans, but the poor knowledge of polychaete taxonomy and the low level of quantitative data might well be one reason for this unusually high percentage.

The zoogeography of the Magellan region has been reviewed several times, but despite these studies the gain of knowledge has remained comparatively poor. Balech (1954) was the first to propose a scheme for the Magellan region, subdividing it into 5 districts: two on the Atlantic side (Santacruceño and Chubutiano), two on the Pacific side (Valdiviano and Chiloense) and the Fueguino district, which connects both sides at the tip of South America. Fifty-six years later and after several reviews (Viviani, 1979; Brattström and Johanssen, 1983; Carreto, 1983; Stuardo and Valdovinos, 1992; Lancellotti and Vásquez, 1999), Camus (2001) questioned whether the Magellan region as a zoogeographic province should be extended into the Atlantic area off the South American coast.

Based on oceanographic and phytoplankton data, only two divisions at the tip of South America were considered by Longhurst (1998): the Humboldt Current Coastal Province, stretching northwards over the entire Chilean Pacific coast, and the Falkland Coastal Province on the Atlantic side. From the zoogeographical point of view, the discussion about the limits between regions and provinces is still open, and for this reason we call the Magellan region a region and its subdivisions "subregions".

In this context the purpose of this investigation was, using all available polychaete data, to analyse whether the traditional subdivisions of the Magellan region are also recognisable on the basis of distribution patterns of polychaete species. Certainly the amount of information on polychaete distribution patterns is considerable and is based on almost 120 years of descriptive taxonomy. However, to our knowledge no one has ever tried to synthesize this bulk of data. This study checks the existing zoogeographical subdivisions in the Magellan region by using polychaete data (presence/absence) of species in the different regions and analyses the zoogeographical affinities with the Antarctic.

\section{MATERIAL AND METHODS}

\section{Study area}

Based on oceanographic conditions and topography, the tip of South America can be divided into three major areas:

1) Numerous channels and fjords on the Pacific side structured by the last glaciation periods (Syvitski et al., 1987) extend from about $42^{\circ} \mathrm{S}$ to $55^{\circ} \mathrm{S}$ in a section of the South American coastline with a wider shelf (Strub et al., 1998). The mean width of the Pacific continental shelf is $6.54 \mathrm{~km}$ (Gallardo, 1984). This area is under the influence of the Humboldt Current and the Cape Horn Current, both of which are branches of the West Wind Drift Current (WWD). The Subantarctic water can penetrate into the inlets (Silva et al., 1998), whose depth may locally exceed $1000 \mathrm{~m}$. The hydrographical regime is characterised by a strong freshwater input due to high precipitation and concomitant runoff, both producing a strong and shallow pycnocline (Dávila et al., 2002). Sediments are characterised by silt and clay (Murray, 1895), coarser sediments such as pebbles/gravel, and biogenic gravel from molluscs and barnacles which are also present at shallower depths (Brambati et al., 1991). Three permanent ice fields, Campo de Hielo Norte (46-47 $\left.{ }^{\circ} \mathrm{S}\right)$, Campo de Hielo Sur $\left(48-52^{\circ} \mathrm{S}\right)$, and the Cordillera Darwin $\left(54-55^{\circ} \mathrm{S}\right.$; Naruse and Aniya, 1992), are responsible for freshwater supply to the fjord system.

2) The Straits of Magellan (52 $52^{\circ} \mathrm{S}, 70^{\circ} 55^{\prime} \mathrm{W}$ and $53^{\circ} 43^{\prime} \mathrm{S}, 70^{\circ} 17^{\prime} \mathrm{W}$ ) are a natural seaway connecting the Pacific with the Atlantic Ocean. Water depths reach $1200 \mathrm{~m}$ at the western entrance on the Pacific side (Antezana et al., 1992). Currents decrease from $1 \mathrm{~m} \mathrm{~s}^{-1}$ on the Atlantic side of the Straits to $0.2 \mathrm{~m} \mathrm{~s}^{-1}$ in the Paso Ancho (Michelato et al., 1991). Primary production ranges seasonally between 282 and $1000 \mathrm{mg} \mathrm{C} \mathrm{m}^{-2}$ day $^{-1}$ (Guglielmo and Ianona, 1997). Sediments mainly consist of sand and gravel with varying proportions of mud and shell debris; the distribution patterns appear rather heterogeneous, especially in the shallower parts of the Straits (Brambati et al., 1991). 
TABLE 1. - Chronological and synoptic list of expeditions carried out in Magellan waters. In the station list the following symbols represent the various kinds of gear used: D: Dredge; AGT: Agassiz Trawl; T: Trawl; McI: Mac Intyre grab; MG: Multibox corer; PG: Petersen grab; VV: Van Veen grab. (*) Information on species per station or station georeference not available.

\begin{tabular}{|c|c|c|c|c|}
\hline Campaign & Research Vessel & No. of stations & Gear & Source \\
\hline HMS Challenger & "Challenger", & 6 & $\mathrm{D}$ & McIntosh, 1885 \\
\hline Swedish Antarctic Expedition & "Antarctic", & 28 & $*$ & Hartman, 1953 \\
\hline Discovery Expedition & "Discovery", & 1 & $\mathrm{D}, \mathrm{T}$ & Monro, 1930-36 \\
\hline Discovery Expedition & "William Scoresby", & 112 & $\mathrm{D}, \mathrm{T}$ & Monro, 1930-36 \\
\hline Lund Univ. Chile Expedition & "Arauco II'" and ,Galvarino", & 95 & D & Wesenberg-Lund, 1962 \\
\hline Mission du Cap Horn & "Romanche", & $23 *$ & $*$ & Fauvel, 1941 \\
\hline Mar Chile I & "Chipana", & 6 & $\mathrm{D}$ & Hartmann-Schröder, 1965 \\
\hline USNS Eltanin & "Eltanin", & 26 & $\mathrm{D}, \mathrm{T}, \mathrm{PG}$ & Hartman, 1967 \\
\hline Akademic Knipovich & "Akademic Knipovich", & 20 & $*$ & Averince, 1972 \\
\hline Akademic Knipovich & "OB" & $4 *$ & $*$ & Averince, 1972 \\
\hline Walther Herwig $15^{\text {th }}, 36^{\text {th }}$ and $76^{\text {th }}$ & "Walther Herwig", & 71 & $\mathrm{D}, \mathrm{T}$ & Hartmann-Schröder, 1983 \\
\hline Allan Hancock Pacific Expedition & "Vema", & $25 *$ & $\mathrm{~T}$ & Maurer and William, 1988 \\
\hline Italian Oceanographic expedition & "Cariboo & 16 & $\mathrm{D}, \mathrm{VV}$ & Gambi et al., 1999 \\
\hline Shinkai Maru $4^{\text {th }}, 5^{\text {th }}, 10^{\text {th }}$ and $11^{\text {th }}$ & "Shinkai Maru", & $22 *$ & $\mathrm{D}, \mathrm{VV}$ & Brémec et al., 2000 \\
\hline CIMAR Fiordos & "Vidal Gormaz", & 19 & AGT & Montiel et al., 2004 \\
\hline UMAG, data base. & "Lenga", & 3 & $\mathrm{McI}$ & Ríos et al., 2003 \\
\hline Joint Magellan Campaign & "Victor Hensen", & 20 & MG & Present study \\
\hline CIMAR Fiordos & "Vidal Gormaz", & 18 & MG & Present study \\
\hline ANT XIII/4 & "Polarstern", & 4 & MG & Present study \\
\hline
\end{tabular}

3) The Atlantic shelf of the Magellan region extends from the Rio de la Plata to Tierra del Fuego. This region between $38^{\circ} \mathrm{S}$ and $55^{\circ} \mathrm{S}$ comprises the Argentine Patagonian shelf and the Falkland/Malvinas plateau. The continental shelf widens to a maximum of about $850 \mathrm{~km}$ at $51^{\circ} \mathrm{S}$ (Piccolo, 1998). The hydrographic regime is structured by the confluence of the Falkland/Malvinas and Brazil currents. The mean annual winter temperature in the Falkland Current is $10^{\circ} \mathrm{C}$ and primary production varies between 150 and $500 \mathrm{mg} \mathrm{C} \mathrm{m}^{-2}$ day $^{-1}$ (Longhurst, 1995). The Brazil Current shows a higher annual mean temperature of $22^{\circ} \mathrm{C}$ with variations in the primary production between 115 and $830 \mathrm{mg} \mathrm{C} \mathrm{m}^{-2}$ day $^{-1}$ (Boltovskoy, 1999). In general, the bottom sediments are composed of sand (fine to median size) and silt ( $<2 \mathrm{~mm}$; Bastida et al., 1981). The coarse fraction $>2 \mathrm{~mm}$ prevails near the coast $(<50$ $m$ depth). In the embayments of Peninsula Valdés, Bahía Blanca and San Matías, this fraction has high percentages of biogenic gravel of mollusc, brachiopod and barnacle shells (Bastida et al., op.cit.).

\section{Origin of polychaete data}

The zoogeographical analysis was based on data from 19 different expeditions, with a total of 445 sampling stations from continental shelf areas of the Magellan region. In total data from 519 stations provided the basis for our analysis. Forty-two of these stations were sampled personally during three expeditions with RVs "Victor Hensen" in 1994 (Arntz and Gorny, 1996), "Vidal Gormaz" in 1995 (Mutschke et al., 1996) and "Polarstern" in 1996 (Fahrbach and Gerdes, 1997). The origin of the remaining data is summarised in Table 1.

\section{Data treatment}

The total number of polychaete species used for this data base includes all species records with exact geographical positions (latitude-longitude), and at least the presence of 1 individual per finding. The sea surface around the tip of South America was divided into 96 quadrants, each one degree longitude and one degree latitude in size. Quadrants without polychaete findings per station were not considered and quadrants with only one station were homologised with the neighbouring quadrants (Fig. 1). The quadrants were enumerated from the Atlantic to the Pacific direction; quadrants 1 to 66 plus quadrant 71 represented the Atlantic sector, quadrants 72-75 represent the Straits of Magellan, and quadrants 67 to 70 plus 76 to 96 represent the Pacific side.

To check whether or not polychaete distribution patterns coincide with the traditional (sub-)divisions of the Magellan region sensu Balech (1954), Carreto (1983), Longhurst (1998), Lancellotti and Vásquez (2000) and Camus (2001), analyses of similarities (ANOSIM) and a Multi-Dimensional Scaling (MDS) between groups of quadrants were carried out. ANOSIM and MDS were performed on the basis of 216 species records from 96 quadrants to 


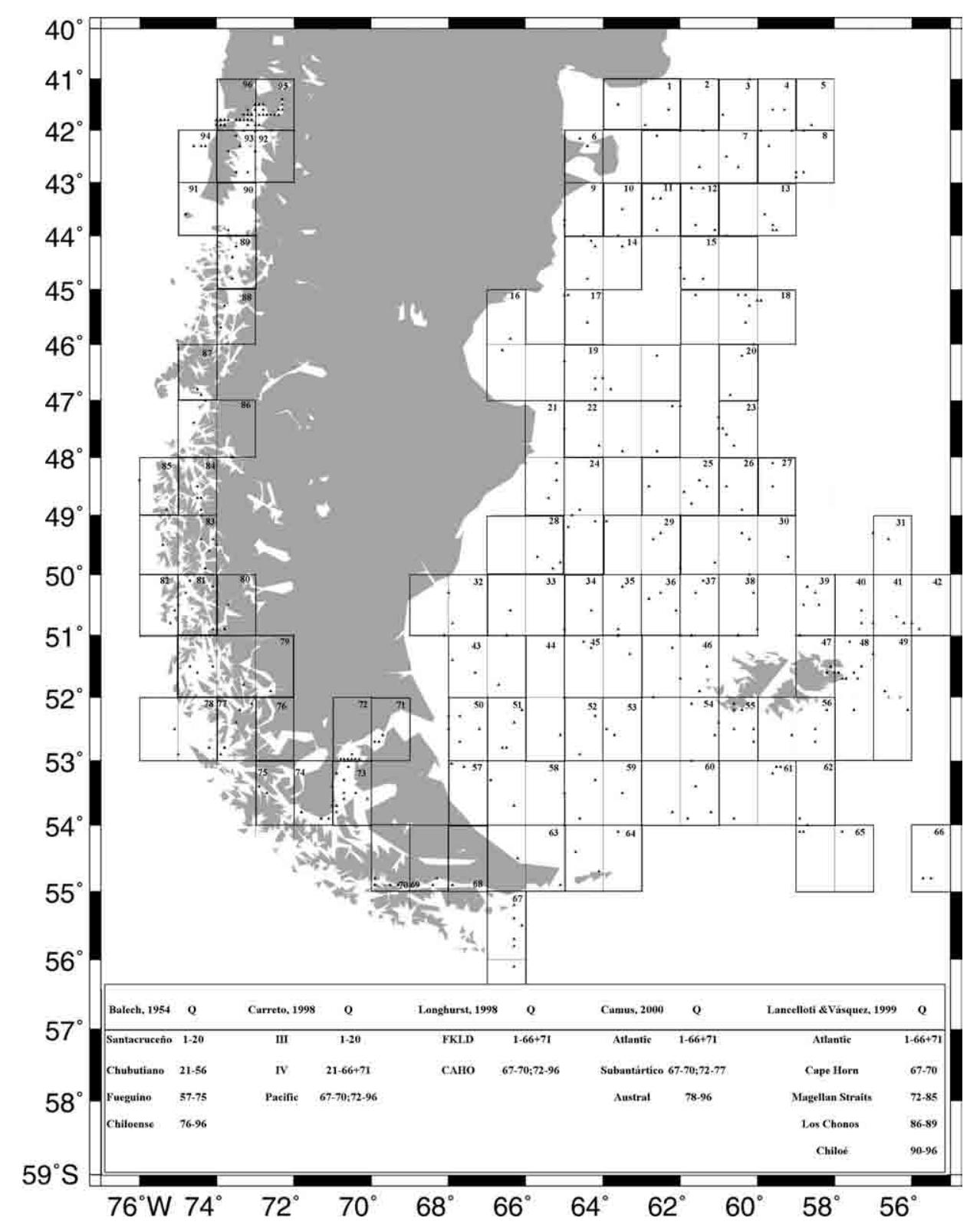

FIG. 1. - Grid of the sea surface off the tip of South America. Dots indicate sampling locations and quadrant numbers and traditional divisions of the Magellan region. A: Atlantic, AU: Austral, C: Chubutiano, CAHO: Cape Horn Province sensu Longhurst (1998), CS: Chiloense, CE: Chiloé, CH: Cape Horn sensu Lancellotti and Vásquez (1999), CI: Chonos Inlet, F: Fueguino, FKLD: Falkland Province, MS: Magellan Straits, PI: Pacific Inlets, S: Santacruceño, SA: Subantarctic (sensu Camus, 2001).

evaluate the dissimilarity between our quadrant groups and the traditional divisions. In the next step the similarity percentage breakdown analysis (SIMPER; Clarke, 1993) describes the contribution of each species to the dissimilarity between the obtained groups of quadrants. All analyses were carried out using the software PRIMER version 5.2.1 (Clarke and Warwick, 1994) with standardised presence/absence data.

The following acronyms were used by the authors for the traditional division of the Magellan region:
A: Atlantic, AU: Austral, C: Chubutiano, CAHO: Cape Horn Province sensu Longhurst (1998), CS: Chiloense, CE: Chiloé, CH: Cape Horn sensu Lancellotti and Vásquez (1999), CI: Chonos Inlet, F: Fueguino, FKLD: Falkland Province, MS: Magellan Straits, PI: Pacific Inlets, S: Santacruceño, SA: Subantarctic (sensu Camus, 2001). For comparison with the adjacent Subantarctic and Antarctic areas south and temperate areas north, additional acronyms $($ ANTA $=$ Antarctic, SANT $=$ Subantarctic and HUMB = Humboldt Current region respectively) were introduced according to Longhurst (1998). 


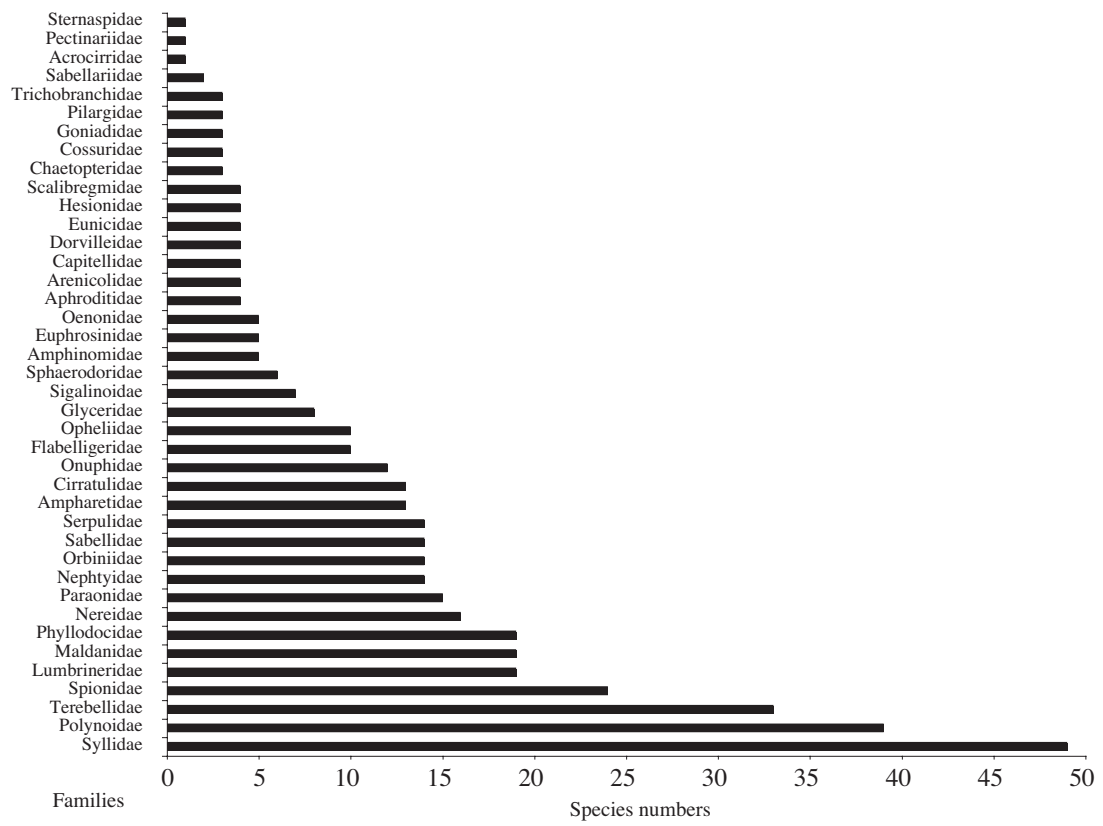

FIG. 2. - Total species number per polychaete family obtained from the study $(n=431)$.

Many of the polychaete species used as discriminators for subregions in the Magellan region also occurred in adjacent and other parts of the world ocean. Because of this, each species was categorised according to its distribution range, basing on the fundamental taxonomic studies of Hartman (1959 a, b) and Rozbaczylo (1985). In addition, the most recent taxonomical reviews for the species distribution of the eunicemorph polychaetes of Orensanz (1990), and the families Spionidae (Blake, 1983), Syllidae (Licher, 1999) and Glyceridae (Böggemann, 2002) were consulted.

\section{RESULTS}

Up to now a total of 431 polychaete species have been recorded for the Magellan region, summarising 124 years of polychaete research in this part of the world. These species were divided into 108 genera and 41 families. The most speciose families were Syllidae, contributing $11 \%$ to the total polychaete species, followed by Polynoidae (9\%), Terebellidae $(8 \%)$, Spionidae $(6 \%)$ and Lumbrinereidae $(4 \%)$, whereas other families were of minor importance $(<$ $4 \%$, Fig. 2).

Out of the 431 polychaete species, 104 species were reported without exact catch positions and another 111 species occurred as single findings, i.e. they were not considered for further analysis. The remaining 216 species thus provided the basis for the numerical and statistical analyses.
TABLE 2. - ANOSIM pairwise test of presence/absence data of polychaete species from quadrants according to the division by the different authors. A: Atlantic AU: Austral C: Chubutiano CAHO: Cape Horn Province CS: Chiloense CE: Chiloe CH: Cape Horn CI: Chonos inlet F: Fueguino FKLD: Falkland Province MS: Magellan Straits PI: Pacific Inlets, S: Santacruceño SA: Subantarctic.* significant difference. $(\mathrm{R}=$ Rank similarities; $\mathrm{P}=$ Probability values $)$

\begin{tabular}{|c|c|c|c|}
\hline $\begin{array}{l}\text { Hypothetical group sensu } \\
\text { different authors }\end{array}$ & $\boldsymbol{R}$ & $\mathrm{P}(\%)$ & $\begin{array}{l}\text { Number } \geq \\
\text { observed }\end{array}$ \\
\hline \multicolumn{4}{|l|}{ Balech, 1954} \\
\hline$S-C$ & 0.2 & 0.2 & 1 \\
\hline$S-F$ & * 0.321 & 0.1 & 0 \\
\hline$S-C S$ & $* 0.557$ & 0.1 & 0 \\
\hline$C-F$ & 0.151 & 0.9 & 8 \\
\hline $\mathrm{C}-\mathrm{CS}$ & $* 0.564$ & 0.1 & 0 \\
\hline F - CS & $* 0.263$ & 0.1 & 0 \\
\hline \multicolumn{4}{|c|}{ Lancellotti and Vásquez 2000} \\
\hline A - CE & 0.342 & 1.5 & 14 \\
\hline A - MS & $* 0.455$ & 0.1 & 0 \\
\hline $\mathrm{A}-\mathrm{CI}$ & * 0.617 & 0.1 & 0 \\
\hline $\mathrm{A}-\mathrm{CH}$ & $* 0.86$ & 0.1 & 0 \\
\hline CE - MS & 0.329 & 2.9 & 28 \\
\hline $\mathrm{CE}-\mathrm{CI}$ & 0.026 & 51.4 & 18 \\
\hline $\mathrm{CE}-\mathrm{CH}$ & 0.476 & 0.6 & 2 \\
\hline MS - CI & 0.244 & 7.5 & 74 \\
\hline MS - CH & * 0.524 & 0.1 & 0 \\
\hline $\mathrm{CI}-\mathrm{CH}$ & 0.31 & 3.3 & 11 \\
\hline \multicolumn{4}{|l|}{ Carreto 1988} \\
\hline III - IV & 0.179 & 0.4 & 3 \\
\hline PI - III & * 0.428 & 0.1 & 0 \\
\hline PI - IV & $* 0.45$ & 0.1 & 0 \\
\hline \multicolumn{4}{|l|}{ Camus 2001} \\
\hline SA - AU & 0.112 & 5.9 & 58 \\
\hline A - SA & $* 0.353$ & 0.1 & 0 \\
\hline A $-\mathrm{AU}$ & $* 0.517$ & 0.1 & 0 \\
\hline \multicolumn{4}{|l|}{ Longhurst 1998} \\
\hline FKLD - CAHO & $* 0.447$ & 0.1 & 0 \\
\hline \multicolumn{4}{|l|}{ Present study } \\
\hline PI - A & * 0.482 & 0.1 & 0 \\
\hline PI - MS & -0.034 & 5.3 & 52 \\
\hline$A-M S$ & 0.237 & 57.8 & 577 \\
\hline
\end{tabular}




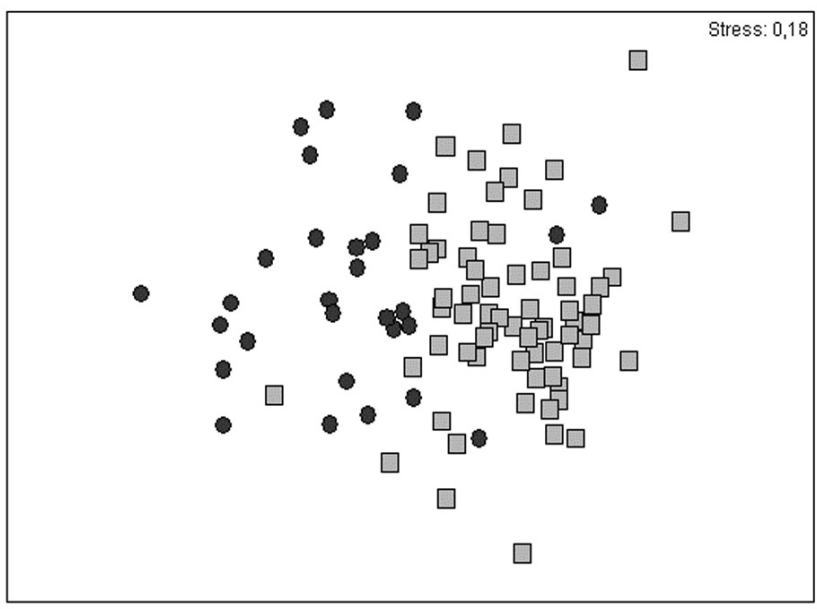

FIG. 3. - MDS ordination plot for the CAHO (circle) and FKLD (squares) regions.

\section{Agreement of polychaete distribution patterns with traditional patterns}

The results of the ANOSIM analysis summarised in Table 2 show the subdivision of the Magellan region into two significant subregions: one on the Atlantic side (FKLD) and one on the Pacific shelf (CAHO). This result resembles that obtained by Longhurst (1998) on the basis of satellite pictures of phytoplankton in surface waters.

The ANOSIM between CAHO and FKLD data revealed a significant difference between the two subregions $(\mathrm{R}=0.4, \mathrm{P}<0.001$; Table 2). The MDS plot confirmed this (Fig. 3) and showed two distinct quadrant groups on the Pacific and the Atlantic shelves of the tip of South America.

TABLE 3. - Results of the SIMPER analysis of presence/absence data of polychaete species from the CAHO and FKLD quadrants. Species are listed in the order of their contribution to the average dissimilarity between both groups after Longhurst (1998). Diss: Dissimilarity; SD: Standard deviation.

\begin{tabular}{|c|c|c|c|c|}
\hline Species & Mean Diss & Diss / SD & Contribution (\%) & Cumulative contribution (\%) \\
\hline Idanthyrsus macropaleus & 2.65 & 0.79 & 2.80 & 2.80 \\
\hline Serpula narconensis & 2.38 & 0.75 & 2.51 & 5.31 \\
\hline Perkensiana antarctica & 2.05 & 0.71 & 2.16 & 7.47 \\
\hline Chaetopterus variopedatus & 1.77 & 0.61 & 1.87 & 9.34 \\
\hline Glycera capitata & 1.72 & 0.62 & 1.81 & 11.15 \\
\hline Onuphis pseudoiridescens & 1.60 & 0.63 & 1.69 & 12.84 \\
\hline Leanira quatrefagesi & 1.57 & 0.68 & 1.66 & 14.50 \\
\hline Ninoe falklandica & 1.55 & 0.56 & 1.64 & 16.14 \\
\hline Polyeunoa laevis & 1.54 & 0.61 & 1.63 & 17.77 \\
\hline Eunice magellanica & 1.52 & 0.53 & 1.61 & 19.38 \\
\hline Maldane sarsi & 1.51 & 0.57 & 1.59 & 20.96 \\
\hline Aglaophamus praetiosus & 1.49 & 0.60 & 1.57 & 22.54 \\
\hline Harmothoe spinosa & 1.47 & 0.65 & 1.55 & 24.09 \\
\hline Nicon maculata & 1.47 & 0.58 & 1.55 & 25.64 \\
\hline Platynereis australis & 1.28 & 0.47 & 1.35 & 26.99 \\
\hline Melinna cristata cristata & 1.27 & 0.52 & 1.34 & 28.33 \\
\hline Harmothoe magellanica & 1.19 & 0.53 & 1.26 & 29.59 \\
\hline Abyssoninoe abyssorum & 1.17 & 0.54 & 1.24 & 30.82 \\
\hline Perinereis nuntia vallata & 1.16 & 0.39 & 1.22 & 32.05 \\
\hline Gymnonereis hartmannschroederae & 1.15 & 0.53 & 1.22 & 33.27 \\
\hline Amphitrite kerguelensis & 1.13 & 0.56 & 1.19 & 34.46 \\
\hline Eunereis patagonica & 1.06 & 0.51 & 1.12 & 35.58 \\
\hline Syllis (Syllis) sclerolaema & 1.05 & 0.46 & 1.10 & 36.68 \\
\hline Kinbergonuphis dorsalis & 0.92 & 0.45 & 0.97 & 37.65 \\
\hline Trypanosyllis gigantea & 0.90 & 0.47 & 0.95 & 38.60 \\
\hline Glycinde armata & 0.90 & 0.42 & 0.95 & 39.55 \\
\hline Sternaspis scutata & 0.89 & 0.43 & 0.94 & 40.49 \\
\hline Harmothoe campoglacialis & 0.88 & 0.45 & 0.92 & 41.41 \\
\hline Thelepus plagiostoma & 0.85 & 0.43 & 0.90 & 42.31 \\
\hline Hyalinoecia artifex & 0.85 & 0.33 & 0.89 & 43.21 \\
\hline Austrolaenilla antarctica & 0.82 & 0.41 & 0.86 & 44.07 \\
\hline Typosyllis armillaris & 0.78 & 0.36 & 0.83 & 44.90 \\
\hline Nereis eugeniae & 0.78 & 0.48 & 0.83 & 45.72 \\
\hline Lumbrineris cingulata & 0.77 & 0.52 & 0.82 & 46.54 \\
\hline Nothria anoculata & 0.75 & 0.37 & 0.79 & 47.33 \\
\hline Nicolea chilensis & 0.74 & 0.42 & 0.79 & 48.12 \\
\hline Lumbrineris magalhaensis & 0.72 & 0.45 & 0.76 & 48.88 \\
\hline Autolytus charcoti & 0.70 & 0.35 & 0.74 & 49.62 \\
\hline Marphysa aenea & 0.70 & 0.30 & 0.74 & 50.36 \\
\hline Aphelochaeta cincinnata & 0.69 & 0.39 & 0.73 & 51.09 \\
\hline Phylo felix & 0.67 & 0.46 & 0.71 & 51.80 \\
\hline Aphrodita longicornis & 0.65 & 0.29 & 0.69 & 52.49 \\
\hline
\end{tabular}




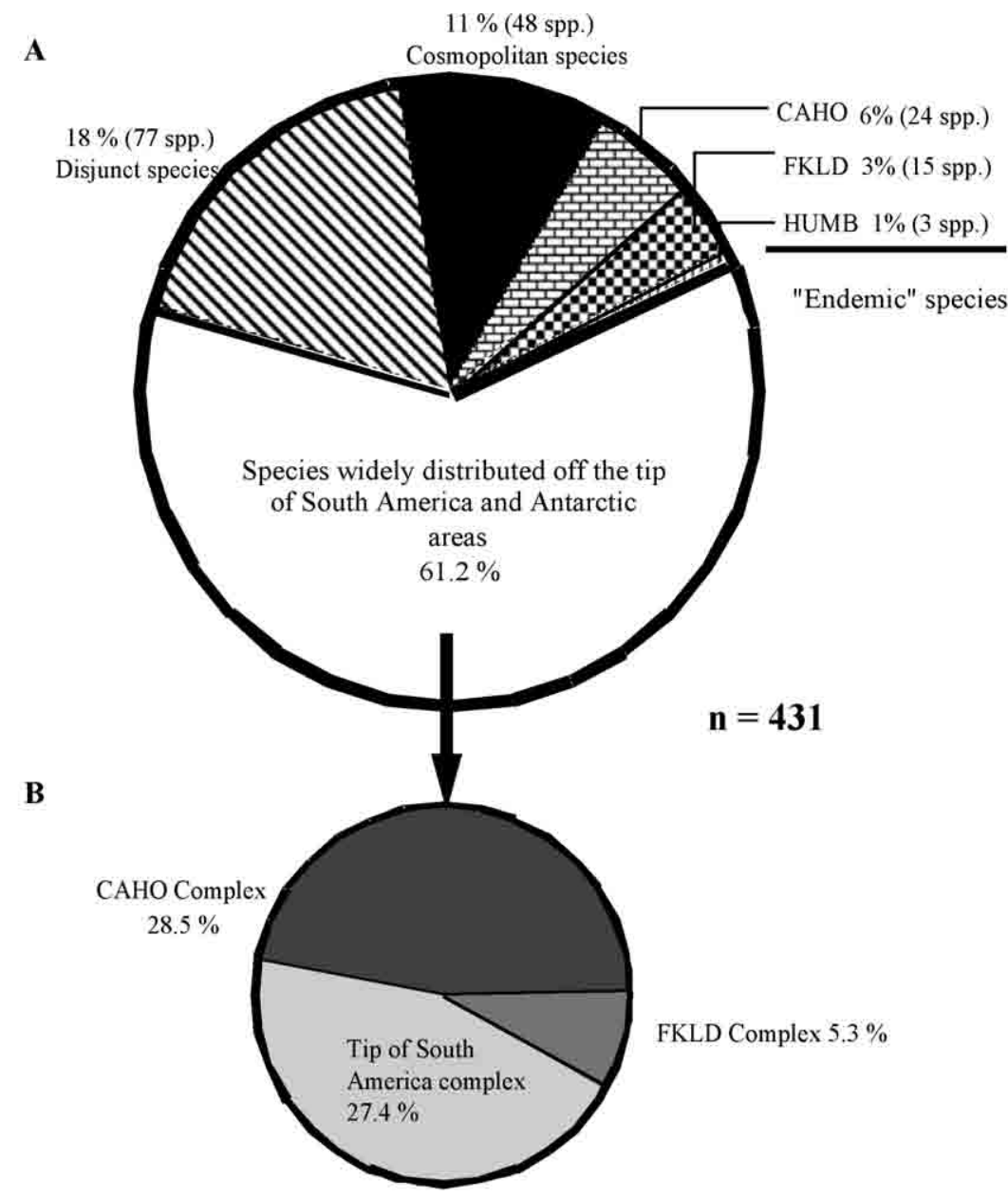

\begin{tabular}{llllll}
\multicolumn{1}{c}{ CAHO Complex } & \multicolumn{3}{c}{$\begin{array}{c}\text { Tip of South America } \\
\text { complex }\end{array}$} & \multicolumn{2}{c}{ FKLD Complex } \\
HUMB-CAHO-SANT & 2 & CAHO-FKLD & 42 & FKLD-ANTA & Spp \\
HUMB-CAHO-SANT-ANTA & 5 & HUMB-CAHO & 57 & FKLD-SANT & 1 \\
CAHO-ANTA & 12 & HUMB-CAHO-FKLD & 19 & FKLD-SANT-ANTA & 5 \\
CHA-SANT & 32 & & & FKLD-CAHO-ANTA & 3 \\
CAHO-SANT-ANTA & 72 & & FKLD-CAHO-SANT & 5 \\
& & & FKLD-CAHO-SANTA-ANTA & 6 \\
& & & & FKLD-HUMB-CAHO-ANTA & 1
\end{tabular}

FIG. 4. - Graph A shows the percentage of species numbers characterised by the geographical range distribution of each polychaete species in the Magellan region, including CAHO: Cape Horn subregion; FKLD: Falkland subregion, HUMB: Humboldt subregion: C: cosmopoli$\tan$; D: disjunct species and the percentage of an arbitrary group of species widely distributed off South America and in the Antarctic. Graph B shows further subdivisions of the arbitrary species group, including different combination of geographical range distribution of species numbers with affinity to the Subantarctic areas (SANT) and Antarctic areas (ANTA). Number in brackets shows absolute species number.

Considering these results, SIMPER was performed between the FKLD and CAHO data to identify the main contributor species for the average dissimilarity (average $=94.75$ ) and the possible differences in species composition between these shelves off the tip of South America. In FKLD the main contributor species with highest occurrence were Idanthyrsus macropaleus, Serpula narconensis, Perkensiana antarctica, and Chaetopterus variopedatus, whereas in the CAHO group species such as Glyc- era capitata, Onuphis pseudoiridescens, Leanira quatrefagesi and Ninoe falklandica were better discriminators between the two subregions (Table 3).

\section{Distribution patterns of polychaetes in the Magellan region and affinities with the Antarctic}

The distribution patterns of the polychaete fauna are shown in Figures 4 a, b. These figures considered all 431 species known from the Magellan region. 
Seventy-seven species (18\%) appeared with disjunctive findings worldwide. Forty-eight species (11\%) showed a cosmopolitan distribution. Only rather low percentages of the polychaete species of the present study were restricted to just one of the distinguished subregions: $4 \%$ to the Atlantic side and $6 \%$ to the southern Pacific side, whereas another $1 \%$ occurred exclusively along the Pacific coast of South America north of $42^{\circ} \mathrm{S}$. Most of the remaining species (61\%) showed an overlapping distribution pattern everywhere along the South American coasts and down to Antarctica. Because of the complexity and a high number of species with overlapping distribution patterns, we divided the remaining species into three arbitrary groups representing the best fit to our abovementioned results (Fig. 4b).

The biggest of these groups (123 species) showed close affinities to the CAHO area. The species were distributed along the Pacific coast of South America towards high Antarctic waters, and some species even extended their northern distribution limit over $42^{\circ} \mathrm{S}$ into more temperate regions.

The smallest group (5\%) showed closest affinities between the FKLD area on the Atlantic side and waters south of the Antarctic Convergence. Another distinct group of species occurred in Atlantic and Pacific waters around the tip of South America, some of them even extending beyond $42^{\circ} \mathrm{S}$ latitude northwards.

\section{DISCUSSION}

\section{Species numbers and structure of the polychaete fauna in the Magellan region}

Based on the 431 species considered in this study, the polychaete fauna was dominated by the families Syllidae, Polynoidae, and Terebellidae. This dominance was described before in the classical polychaete reviews of Orensanz (1974) and Knox and Lowry (1977) on the basis of 397 and 223 species respectively. In our study Spionidae followed as the next important family in the fourth position, whereas Phyllodocidae occupied this rank in the studies of Orensanz (1974) and Knox and Lowry (1977). The latter sequence also resulted in the biodiversity review of Clarke and Johnston (2003) for the whole Southern Ocean and the study of Rozbaczylo (1985) for the southeastern Pacific coast.

Since the studies of Knox and Lowry and Orensanz in the mid-1970s, 32 new records and 2 new species have been described for the Magellan region (Gambi and Mariani, 1999; Hilbig and Montiel, 2000; Montiel and Hilbig 2004). This increase may be explained to some extent by new expeditions in the 1980s and 1990s. Many of these species, however, occurred as "single findings" or "disjunctive species", i.e. due to few and scattered records, wide distribution ranges, and/or uncertain taxonomical status they did not have much value for zoogeographical analyses. Therefore our database for the zoogeographical analysis consisted of fewer than the 431 species described for the Magellan region in total. Our results showed 111 species which occurred as single records at the tip of South America. This agrees with the analyses of the macroinvertebrate fauna along the Chilean coast (Lancellotti and Vásquez, 1999). These authors also described this area as a zone with a high number of single records of species, which may be a result of insufficient numbers of surveys in this region.

\section{Zoogeographical patterns of the polychaete fauna}

Based on the polychaete presence/absence data, the Magellan region can be subdivided into Pacific and Atlantic subregions. A similar pattern results from the satellite plankton discrimination of Longhurst (1998). Due to the composition of the plankton under the influence of the Humboldt Current system and the Cape Horn Current this area is called Humboldt Province. However, in our analysis species occurring in the Humboldt area were poorly represented, and we therefore propose a different name for this zoogeographic area, the Cape Horn subregion (CAHO).

In the last decade marine zoogeographical studies based on macroinvertebrates from the Pacific coast of South America have been performed exclusively with data from old literature (Fernández et al., 2000, Lancellotti and Vasquez, 1999; Camus, 2001). These authors have given strong emphasis to the traditional zoogeographical barriers along the Chilean coastline, as proposed by Viviani (1979) and Brattström and Johanssen (1983) - for example the $42^{\circ} \mathrm{S}$ barrier between the Magellan region in the south and the adjacent temperate region to the north - and along the Atlantic coastline, as proposed by Balech (1954). However, this traditional barrier does not exist for many polychaete species, as is obvious from the high percentage of overlapping species with a wide range of distribution and the 
high number of common species north and south of $42^{\circ} \mathrm{S}$. One reason could be an enormous ecological capacity and tolerance of polychaetes to very different environmental conditions, as is typical of organisms of phylogenetically old lineage (Fauchald, 1984). Another reason may be local oceanographic conditions (see below).

The marine realm is a dynamic system, i.e. fixed borderlines hardly occur. Absolute barriers in aquatic systems are almost impossible, and for many species borders probably act more as filters than as barriers, allowing species exchange in both directions (Dell, 1972; Scheltema, 1988; Hilbig, 1994; Boltovskoy, 1999).

Do our arbitrary groups (Fig. 4) correspond to polychaete distribution patterns and how could these patterns be explained? We distinguished two groups with species showing a high affinity to Antarctic waters and one group that was restricted to South American shelf areas. Within the first two groups one group contained $28.5 \%$ of the species, showing affinity between Pacific and Antarctic waters, and a smaller second group (5.3\%) showed affinity between Atlantic and Antarctic waters. The processes and mechanisms behind these patterns are controversially discussed in the literature (Orensanz, 1990). Two different explanations are under discussion: a) common species in both areas (Pacific-Antarctic or Atlantic-Antarctic) occur due to the common history of the areas as parts of Gondwana (vicariance) and b) common species occur due to dispersion of meroplanktonic larvae (dispersalism). We suggest that dispersion of Antarctic species through larval transport via easterly directed currents of the West Wind Drift (WWD) plays an important role in the current distribution patterns of the fauna around the tip of South America. This hypothesis is supported by a higher proportion of species with higher Antarctic affinities to the Pacific coast as compared to the relatively small proportion of species with affinities to the Atlantic side. However, according to Bhaud (1998) the spreading potential of polychaete larvae does not necessarily predict the adult distribution. Key processes for the establishment of a successful population in a new habitat are especially the recruitment conditions and the substrate choice of settling larvae (Bhaud op. cit). The presence of common species on both sides of the Drake Passage provides strong evidence to argue that dispersion might be an important process for faunal exchange between the Magellan region and Antarctica. The Polar Front does not therefore function as a strict barrier for many species. In fact, several of the dominating polychaete species in the Magellan area as defined by the SIMPER analysis (I. macropaleus, S. narconensis, $C$. variopedatus, $L$. quatrefagesi) reproduce via meroplanktonic larvae (Giangrande, 1997). Another hypothesis includes the adjacent deep-sea areas as possible sources for shelf species. However, potential pathways of recolonisation of shelf communities from the deep sea are still under study and hardly understood. The results of the recent "ANDEEP" and "LAMPOS" expeditions (Fütterer et al., 2003; Arntz and Brey, 2003) might be particularly important to present keystones in the overall Antarctic-Magellan puzzle.

Finally, we suggest that the last group restricted to the tip of South America and occurring exclusively in South American waters with its high number of common species on the Pacific and Atlantic side is the result of the glaciation history of the southern parts of South America. The southeastern Magellan region is a geologically young system (Pisano, 1990), which was ice-covered during the Last Glacial Maximum some 12,000 years BP (Clapperton et al., 1995; Benn and Clapperton, 2000). All present polychaete species in Magellan waters recolonised this area from adjacent Atlantic and Pacific areas. Moreover, the Straits of Magellan have been an important corridor for species exchange between both sides since the opening 7,000 year BP (McCulloch and Davies, 2001). The oceanography of this area reflects the intrusion of oceanic waters from both sides of the continent and the mixture of these water masses in the Paso Ancho in the middle of the Straits. We suggest that the opening of the Straits of Magellan created a new pathway for enhanced exchange of faunal elements from the Pacific to the Atlantic and vice-versa.

\section{ACKNOWLEDGEMENTS}

We are grateful to Prof. Erika Mutschke and the Comité Oceanográfico Nacional (CONA) for providing the biological material from the CIMARFiordo expedition. This work was supported by DAAD grant No A/00/10932.

\section{REFERENCES}

Arntz, W. and M. Gorny. - 1996. Cruise report of the joint ChileanGerman-Italian "Victor Hensen" campaign in 1994. Ber. Polarforsch., 190: 1-113. 
Arntz, W. and T. Brey. - 2003. The expedition ANTARKTIS XIX/5 (LAMPOS) of RV "Polarstern" in 2002. Ber. Polarforsch., 462: 1-120.

Antezana, T., L. Guglielmo and E. Ghirardelli. - 1992. Microbasins within the Strait of Magellan affecting zooplankton distribution. In: V.A. Gallardo, O. Ferretti and H. I. Moyano (eds.), Oceanografía en Antártica, pp. 453-458. Ediciones Documentadas, Santiago.

Averince, V.G. - 1972. Benthic polychaetes Errantia from Antarctic and Subantarctic collected by the Sovietic Antarctic expedition, 5. Bio. Res. Sov. Ant. Exp., 5: 88-293.

Balech, E. - 1954 Divisiones zoogeográficas del litoral sudamericano. Rev. Biol. Mar., 4: 184-195.

Bastida, R., C. Urien, V. Lichtschein, A. Ruox and P. Arias. - 1981. Investigación sobre comunidades bentónicas. Características generales del sustrato (Campañas IV, V, X y XI del B/I "Shinkai Maru"). Contrib. Inst. Nac. Inv. Des. Pesq, 383: 318-339.

Blake, J. - 1983. Polychaetes of the family Spionidae from South America, Antarctica and adjacent seas and islands. Antarct. Res. Ser. 29: 205-288.

Blake, J. - 1995. Introduction to the Polychaeta. Chapter 4. In: J. Blake, C. Erséus and B. Hilbig (eds.), Taxonomic atlas of the benthic fauna of the Santa Maria Basin and western Santa Barbara Channel, pp. 39-51 Santa Barbara Museum of Natural History. California.

Bhaud, M. - 1998. The spreading potential of polychaete larvae does not predict adult distributions; consequences for conditions of recruitment. Hydrobiologia, 375/376: 35-47.

Benn, D. and C. Clapperton. - 2000. Glacial sediment-landform associations and paleoclimate during the last glaciation, Strait of Magellan, Chile. Quat. Res., 54: 13-23.

Boltovskoy, D., M. Gibbons, L. Hutching and D. Binet. - 1999. General biological features of the South Atlantic. In: D. Boltovskoy (ed.), South Atlantic zooplankton (1): 1-42 pp. Backhuys Publishers, Leiden, The Netherlands.

Böggemann, M. - 2002. Revision of the Glyceridae Grube 1850 (Annelida: Polychaeta). Abh. Senckenb. Naturforsch. Ges., 555: 1- 249

Bouchet, P. - 2000. L'insaisissable inventaire des espèces. La recherche 333: 40-44.

Brambati, A., G. Fontolan and U. Simeoni. - 1991. Recent sediments and sedimentological processes in the Straits of Magellan. Mem. Biol. Mar. Ocean., 19: 217-259.

Brattström, H. and A. Johanssen. - 1983. Ecological and regional zoogeography of the marine benthic fauna of Chile. Sarsia, 68: 289-339.

Brémec, C., R. Elías and M. Gambi. - 2000. Comparison of the polychaete fauna composition from the Patagonian shelf and Straits of Magellan. Preliminary results from cruise Shinkai Maru IV, V, X and XI (1978-1979) and second Italian Oceanographic Cruise (1991). Bull. Mar. Sci., 67(1): 189-198.

Camus, P.A. - 2001. Biogeografía marina de Chile continental. Rev. Chil. Hist. Nat., 74: 587-617.

Carreto, J. - 1983. Los ecosistemas del Mar Argentino. In: "Proyecto El medio ambiente marino en relación a los recursos pesqueros".

Clapperton, C., D. Sugden, D. Kaufman and R. McCulloch. - 1995. The last glaciation in the central Magellan Strait, southernmost Chile. Quat. Res., 44(2):133-148.

Clarke, A. and N. Johnston. - 2003. Antarctic marine benthic diversity. Oceanogr. Mar. Biol. Ann. Rev., 41: 47-114.

Clarke, K. and R. Warwick. - 1994. Similarity-based testing for community pattern: The two-way layout with no replication. Mar. Biol., 118: 167-176.

Clarke, K.R. - 1993. Non-parametric multivariate analyses of changes in community structure. Aust. J. Ecol., 18: 117-143.

Dávila, P., D. Figueroa and E. Müller. - 2002. Freshwater input into the coastal ocean and its relation with the salinity distribution off austral Chile $\left(35-55^{\circ} \mathrm{S}\right)$. Cont. Shelf. Res., 22: 521-534.

Dell, R. K. - 1972. Antarctic benthos. Adv. Mar. Biol., 10: 2-172.

Fahrbach, E. and D. Gerdes. - 1997. Die Expedition ANTARKTIS XIII/4-5 des Forschungsschiffes "Polarstern" 1996. Ber. Polarforsch. 239: 1-126.

Fauchald, K. - 1984. Polychaete distribution patterns, or: can animals with Palaeozoic cousins show large-scale geographical patterns? In: P.A. Hutchings (ed.), Proceedings of the First International Polychaete Conference, pp. 1-6. Linnean Society of New South Wales.
Fauvel, P. - 1941. Annélides polychètes de la Mission du Cap Horn (1882-1883). Bull. Mus. Hist. Nat. Paris, sér. 2., 13(4): 272298.

Fernández, M., E. Jaramillo, P. Marquet, C. Moreno, S. Navarrete, P. Ojeda, C. Valdovinos and J. Vásquez. - 2000. Diversidad, dinámica y biogeografía del ecosistema costero bentónico de Chile: revisión y bases para la conservación marina. Rev. Chil. Hist. Nat., 73(4): 797-830.

Fütterer, D., A. Brandt and G. Poore. - 2003. The expedition ANTARKTIS XIX/3-4 (ANDEEP 1 and II) of the R/V POLARSTERN in 2002. Ber. Polarforsch., 470: 1-174

Gambi, M. and S. Mariani. - 1999. Polychaetes of the soft bottoms of the Straits of Magellan collected during the Italian oceanographic cruise in February-March 1991. In: W.E. Arntz and C. Ríos (eds.), Magellan-Antarctic: Ecosystems that drifted apart. Sci. Mar., 63(Suppl. 1): 233-242.

Gallardo, V. A. - 1984. Revisión actualizada a 1983 de la contaminación marina proveniente de fuentes terresteres en la región del Pacífico sudeste (Colombia, Chile, Ecuador, Panamá y Perú). Rev. Com. Per. Pac., 14: 19-173.

Giangrande, A. - 1997. Polychaete reproductive patterns, life cycles and life histories: an overview. Oceanogr. Mar. Biol., 35: 323-386.

Glasby, J. and B. Alvarez. - 1999. Distribution patterns and biogeographic analysis of Austral Polychaeta (Annelida). J. Biogeogr., 26: 507-533.

Guglielmo, L. and A. Ianora. - 1997. Atlas of marine zooplankton. Strait of Magellan: amphipods, euphausiids, mysids, ostracods and chaetognaths. Springer-Verlag, New York.

Hartman, O. - 1953. Non-pelagic Polychaeta of the Swedish Antarctic expedition 1901-1903. In: Further zoological results of the Swedish Antarctic Expedition 1901-1903 under the direction of Dr. Otto Nordenskjöld. Edited by N. H. Odhner Vol. 4: 1-83. P. A. Norstedt and Söner, Stockholm.

Hartman, O. - 1959a. Catalogue of the polychaetous annelids of the world. Part I. Allan Hancock Found. Publ. Occ. Pap., 23: 1-353.

Hartman, O. - 1959b. Catalogue of the polychaetous annelids of the world. Part II. Allan Hancock Found. Publ. Occ. Pap., 23: $355-628$.

Hartman, O. - 1967. Polychaetous annelids collected by the USNS Eltanin and Staten Island cruises, chiefly from Antarctic seas. Allan Hancock Monogr. Mar. Biol., 2: 1-328.

Hartmann-Schröder, G. - 1965. Zur Kenntnis des Sublitorals der chilenischen Küste unter besonderer Berücksichtigung der Polychaeten und Ostracoden. II. Die Polychaeten des Sublitorals. Mitt. Hamburg. Zool. Mus. Inst., 62(Suppl.): 59-305.

Hartmann-Schröder, G. and G. Hartmann. - 1974. Zur Kenntnis des Eulitorals der afrikanischen Westküste zwischen Angola und Kap der Guten Hoffnung und der afrikanischen Ostküste von Südafrika und Mocambique unter besonderer Berücksichtigung der Polychaeten und Ostracoden. Mitt. Hamburg. Zool. Mus. Inst., 69: 5-94.

Hartmann-Schröder, G. - 1983. Die Polychaeten der 15., 36. und 76. Reisen von FFS "Walter Herwig" zum patagonischen Shelf (Südwest-Atlantik). Senckenbergiana Mar., 15(4): 251-277.

Hilbig, B. - 1994. Faunistic and zoogeographical characterization of the benthic infauna on the Carolina continental slope. DeepSea Res. II., 41: 929-950.

Hilbig, B. and A. Montiel. - 2000. Harmothoe campoglacialis sp. nov. (Polychaeta: Polynoidae), a new scaleworm from the Magellan region, Chile. Mitt. Hamb. Zool. Mus. Inst., 97: 5-12.

Hutchinson, P. - 1998. Biodiversity and functioning of polychaetes in benthic sediments. Biodiversity Conserv., 7: 1133-1145.

Knox, G. - 1957. The distribution of the polychaetes within the Indo-Pacific. Proc. $8^{\text {th }}$ Pacif. Sci. Congr., 3: 403-411.

Knox, G. and K. Lowry. - 1977. A comparison between the benthos of the Southern Ocean and the North Polar ocean with special reference to the Amphipoda and Polychaeta. In: M.J. Dunbar (ed.) Polar ocean, pp 423-462. Arctic Institute of North America, Calgary.

Lancellotti, D.A. and J. Vásquez. - 1999. Biogeographical patterns of benthic macroinvertebrates in the Southeastern Pacific littoral. J. Biogeogr., 26: 1001-1006.

Lancellotti, D.A. and J. Vásquez. - 2000. Zoogeografía de macroinvertebrados bentónicos de la costa de Chile: contribución para la conservación marina. Rev. Chil. Hist. Nat., 73: 99-129.

Licher, F. - 1999. Revision der Gattung Typosyllis Langerhans, 1879 (Polychaeta: Syllidae): Morphologie, Taxonomie and 
Phylogenie. Abh. Senckenb. Naturforsch. Ges., 551: 1-336.

Longhurst, A. - 1998. Ecological geography of the sea. Academic Press.

Longhurst, A. - 1995. Seasonal cycles of pelagic production and consumption. Prog. Oceanogr., 36: 77-167.

Maurer, D. and S. Williams. - 1988. Deep-sea polychaetous Annelida from Central America to the Antarctic Peninsula and Sandwich Islands. Int. Revue. Ges. Hydrobiol., 73: 659-701.

McCulloch, R. and S. Davies. - 2001. Late-glacial and Holocene palaeoenvironmental change in the central Strait of Magellan, southern Patagonia. Palaeogeogr. Palaeocl., 173: 143-173.

McIntosh, W.C. - 1885. Report on the Annelida Polychaeta collected by H.M.S. Challenger during the years 1873-1876. In: Report on the scientific results of the voyage of H.M.S. Challenger during the years 1873-1876 under the command of Captain George S. Nares, R.N., F.R.S. and the late Captain Frank Tourle Thomson, R.N., Zoology, 12(34): 1-554, pls. 1-55, and $1 \mathrm{a}-39 \mathrm{a}$

Michelato, A., E. Accerboni and P. Berger. - 1991. Current meter observations in the eastern and central sectors of the Strait of Magellan. Mem. Biol. Mar. Ocean., 19: 261-272.

Monro, C. - 1936. Polychaete worms. II. Discovery Rep., 12: 59-138.

Montiel, A. and B. Hilbig. - 2004. Aricidea pisanoi (Annelida: Polychaeta), a new species of Paraonidae from the southernmost waters of South America (Chile). J. Mar. Biol. Ass. UK, $84: 43-45$

Montiel, A., C. Ríos, E. Mutschke and N. Rozbaczylo. - 2004. Poliquetos de fiordos y canales adyacentes al Campo de Hielo Patagónico Sur, Chile (Annelida: Polychaeta). Cs. Tecl. Mar., 27(1): 49-67

Murray, J. - 1895. A summary of the scientific results obtained at the sounding, dredging and trawling station of H.M.S. Challenger. Challenger Rep., 2: 817-822.

Mutschke, E. C. Ríos, T. Hromic, M. Gorny, A. Montiel, M. Rauschert and D. Gerdes. - 1996. Estudios bentónicos en fiordos y canales de los Campos de Hielo Sur $\left(45^{\circ}-53^{\circ} \mathrm{S}\right)$. In Comité Oceanográfico Nacional (eds.), Resultados Crucero CIMAR - FIORDO 2, 14 de octubre al 9 de noviembre 1996, resúmenes ampliados, pp. 91-98.

Naruse, R. and M. Aniya. - 1992. Outline of Glacier Research Project in Patagonia, 1990. Bull. Glacier Res., 10: 31-38.

Orensanz, J. - 1974. Anélidos poliquetos de la provincia bio- geográfica magallánica I. Catálogo de las especies citadas hasta 1974. Contrib. Tec., 1: 1-83.

Orensanz, J.M. - 1990. The eunicemorph polychaete annelids from Antarctic and Subantartic seas. With addenda to the Eunicemorpha of Argentina, Chile, New Zealand, Australia, and the southern Indian Ocean. Biology of the Antarctic Seas XXI. Antarct, Res. Ser., 52: 1-183.

Piccolo, M.C. - 1998. Oceanography of the western South Atlantic continental shelf from 33 to $5^{\circ} \mathrm{S}$ coastal segment. In: A.R. Robinson, K.H. Brink (eds.), The sea, pp. 253-271. Wiley and Sons, New York.

Pisano, E. - 1990. Labilidad de los ecosistemas terrestres fuegopatagónicos. Ans. Ins. Pat. Ser. Cs. Nts., 19: 17-25.

Ríos, C., E. Mutschke and E. Morrison. - 2003. Biodiversidad bentónica en el Estrecho de Magallanes, Chile. Rev. Biol. Mar. Oceanog., 38: 1-12.

Rozbaczylo, N. - 1985. Los anélidos poliquetos de Chile. Indice sinonímico y distribución geográfica de especies. Monograf. Biol., 3: 1-284.

Scheltema, R.S. - 1988. Initial evidence for the transport of teleplanic larvae of benthic invertebrates across the East Pacific barrier. Biol. Bull., 174: 145-152.

Silva, N. and R. Prego. - 1998. Carbon and nitrogen spatial segregation and stoichiometry in the surface sediments of Southern Chilean inlets $\left(41^{\circ}-56^{\circ} \mathrm{S}\right)$. Estuar. Coast. Shelf. Sci., 55: 763-775.

Stuardo, J. and C. Valdovinos. - 1992. Barreras, límites faunísticos y provincias biogeoquímicas en Sudamérica austral. In: V.A. Gallardo, O. Ferretti and H.I. Moyano (eds.), Oceanografia in Antartide: atti seminario internazionale, pp. 443-452. ENEA/Centro EULA, Concepción, Chile.

Strub, P., J. Mesías, V. Montecino, J. Rutllant and S. Salinas. 1998. Coastal ocean circulation off western South America coastal segment. Chapter 10. In: A.R. Robinson, K.H. Brink (eds.), The sea, pp. 273-313. Wiley and Sons, New York.

Syvitski, J.P.M., D.C. Burrell and J.M. Skei. - 1987. Fjords: processes and products. Springer-Verlag, New York.

Viviani, C. - 1979. Ecogeografia del litoral chileno. Studies on Neotropical Fauna and Environment, 14: 65-123.

Wesenberg-Lund, E. - 1962. Polychaeta Errantia. Reports of the Lund University Chile expedition 1948-49. Lunds Univ. Arsskr. N.F. Avd. 2, 57(12): 1-137. 
